\title{
PEMANFAATAN SISTEM PENGERING MENGGUNAKAN MIKROKONTROLER GENUINO UNO DAN SOLAR SEL UNTUK PENGOLAHAN HASIL PERTANIAN MASYAKARAKAT DESA PASAR PEDATI DAN DESA HARAPAN
}

\section{UTILIZATION OF DRYING SYSTEM USING GENUINO UNO MICROCONTROLLER AND SOLAR CELL FOR PROCESSING OF AGRICULTURAL PRODUCTS OF PASAR PEDATI AND HARAPAN VILLAGE PEOPLE}

\author{
Oleh: \\ Anizar Indriani, ST.MT, Dr. Eng Hendra ST.MT, Yovan witanto, ST.MT \\ Program Studi Teknik Elektro Universitas Bengkulu \\ Email:aniz_raimin@yahoo.com
}

\begin{abstract}
The daily life of the people in Pasar Pedati Village and Harapan Village, Central Bengkulu Regency, especially the housewives is processing agricultural products such as cassava, copra, and banana. Cassava is made into cassava chips and rengginang. This devotional activity aims to transfer technology and science in processing agricultural products and help villagers to create versatile dryers. This versatile drying machine works by utilizing solar and heat energy absorbed by copper plates where the heat is insulated using a glass layer. Heat utilization is made by copper plate so it must be made with transparent glass design on the top and around the wall of the dryer. The frame of the glass stand is made of aluminum and is assembled using a rivet. The process of choosing and making of this drying machine involves the people of Pasar Pedati Village and Harapan Village, both men and women. Most of the men in Pasar Pedati Village work on farming and also work outside the village, so that during the day there are housewives working on the process of drying their crops. With this versatile drying machine training, Pasar Pedati and Desa Harapan villagers are particularly enthusiastic in training. Because these dryers are very helpful for them in processing the crops better, cleaner, and the time is not too long. Drying process with this drying machine also does not require a large area. Drying cassava made into cassava chips and rengginang takes about 2-3 hours, compared to manual drying done by drying the open yard takes 12-16 hours. The society can make this tool itself in order to increase their income.
\end{abstract}

Keywords: dryer machine, cassava, aluminum copra, solar cell

\section{PENDAHULUAN}

Ubi kayu atau ketela pohon, pisang dan kelapa merupakan tanaman yang mudah ditemukan dan ditanam di daerah-daerah atau wilayah Indonesia. Tanaman kelapa, pisang dan ubi kayu atau ketela pohon ditanam baik untuk tanaman sayur ataupun tanaman produksi. Tanaman kelapa, pisang dan ubi kayu dapat diambil daun, umbi dan batangnya yang digunakan sebagai sayuran, makanan ringan, makanan tradisional (keripik ubi, kerupuk "balado", rangginang dan kerupuk opak), pakan ternak dan lainnya. Kelapa tua 
dan muda diambil santan atau buahnya, ubi kayu diambil sebagai sayuran yang dapat digunakan secara langsung tanpa memerlukan pengolahan lanjutan seperti pengeringan dan lainnya. Kelapa muda dan umbi ubi kayu yang digunakan sebagai makanan ringan juga tidak memerlukan proses pengolahan lanjutan. Makanan tradisional dari umbi ubi kayu ada yang harus diolah terlebih dahulu setelah dipanen dan ada yang dapat langsung dibuat makanan. Seperti kerupuk ubi dan keripik "balado" merupakan makanan tradisional yang termasuk kedalam proses yang dapat langsung digunakan. Untuk rangginang dan kerupuk opak merupakan makanan yang harus diolah terlebih dahulu seperti proses pengeringan dengan penjemuran, proses penghalusan dengan penggilingan dan pengadukan adonan, proses pembentukan rangginang dan kerupuk opak, penjemuran setelah dibentuk dan lainnya.

Proses pengeringan kelapa, pisang dan ubi kayu masih dilakukan secara tradisional seperti menjemur di area terbuka, di atas jaring jemuran dan pengeringan lain. Dimana pengeringan ini sangat tergantung cuaca, tidak higienis, area yang luas dan waktu pengeringan yang lama. Proses pengeringan yang lama dan kebutuhan ekonomi yang mendesak menyebabkan masyarakat petani kelapa dan umbi ubi kayu sering mengambil dan menjual dalam bentuk mentah seperti kelapa muda, daun ubi kayu dan umbi ubi kayu. Dimana nilai ekonomis hasil kebun ini rendah dibandingkan dengan hasil kebun yang diolah menjadi produk makanan lain.

Desa Pasar Pedati dan Desa Harapan Kecamatan Pondok Kelapa termasuk daerah yang memiliki sumber daya alam seperti ubi kayu, kelapa, pisang dan pemandangan alam. Penghasilan dari masyarakat Desa Pasar Pedati didapatkan dari berkebun ubi kayu, kelapa, pisang dan membuat makanan tradisional. Bahan dasar makanan tradisional didapatkan dari kebun ubi dimana diolah secara tradisional dengan cara alamiah yaitu menjemur di area terbuka. Proses pengeringan secara alamiah ini menjadi kurang higiensi disebabkan oleh masyarakat sekitar memiliki ternak yang dipelihara secara bebas.

Untuk membantu masyarakat petani kelapa dan ubi kayu dalam meningkatkan nilai ekonomis produk kebunnya maka dilakukan pelatihan pembuatan mesin pengering serbaguna untuk hasil kebun seperti ubi kayu, kelapa, pisang dan lainnya.

Proses pengeringan hasil kebun kebanyakan dilakukan oleh masyarakat desa di área terbuka. Dimana proses pengeringan ini sangat bergantung pada kondisi cuaca, área yang luas dan kondisi tempat pengeringan. Nilai ekonomis produk hasil pengeringan tergantung pada cara pengeringan, metode pengeringan dan peralatan pengeringan yang digunakan. Produk hasil perkebunan banyak yang tidak diterima oleh perusahaan besar atau konsumen asing karena produk tersebut diolah dengan kondisi yang tidak layak, tidak higienis dan kualitas yang tidak terkontrol. Gambar 1. menunjukan lahan kebun ubi kayu, kelapa dan proses pengolahan hasil kebun dengan cara pengeringan di área terbuka di Desa Pasar Pedati, dimana pada Gambar 1. terlihat proses penjemuran menggunakan alas (tikar) dan jaring yang diletakkan di tanah atau kayu penyangga.
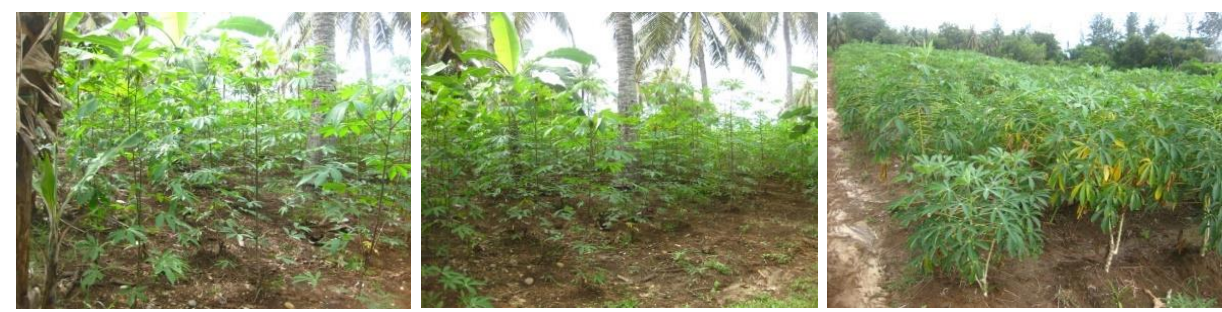

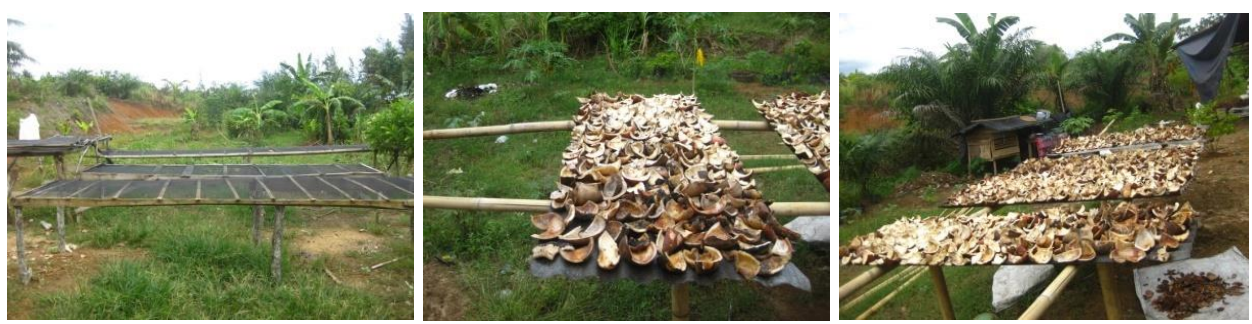

Gambar 1. Kebun Ubi Kayu, Kelapa Dan Proses Pengeringan Alami

Untuk mengolah dan mendapatkan hasil pertanian yang baik maka harus dapat memanfaatkan teknologi pengolahan yang baik, optimum dan bersih. Mesin pengering serbaguna ini termasuk pada proses pengolahan yang dapat mengeringkan produk hasil kebun dalam waktu yang singkat, bersih dan kualitas kadar pengeringan yang dapat dikontrol.

\section{Panel Surya}

Sel surya adalah suatu elemen aktif yang mengubah cahaya matahari menjadi energi listrik. Sel surya pada umumnya memiliki ketebalan minimum $0,3 \mathrm{~mm}$, yang terbuat dari irisan bahan semikonduktor dengan kutub positif dan kutub negatif. Prinsip dasar pembuatan sel surya adalah memanfaatkan efek fotovoltaik, yaitu suatu efek yang dapat mengubah langsung cahaya matahari menjadi energi listrik dilihat pada Gambar 2 (Subandi dan Salmet, 2015).

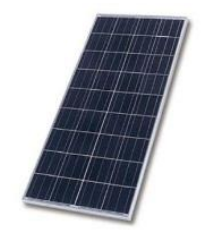

Gambar 2. Panel Surya

\section{Elemen Pemanas (Heater)}

Heater adalah sebuah alat pemanas yang biasanya terbuat dari logam yang berupa lempengan, silinder pejal maupun berupa kawat pejal yang dibentuk menjadi spiral, sedangkan hotplate adalah sebuah pemanas yang berupa piringan yang didalam piringan tersebut terdapat elemen heater yang bisa berupa logam nichrome, tungstenatau lainnya, tetapi sering sekali digunakan sebagai pengganti salah satu pembakar dari berbagai oven atau bagian atas dari kompor masak di lihat pada Gambar 3 (Wijaya, 2011).

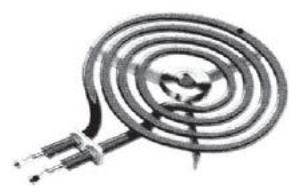

Gambar 3. Elemen Pemanas

\section{Sensor Suhu dan Kelembaban DHT 21}

High Quality Humidity Temperature Sensor AM2301 DHT 21 adalah sensor kelembaban dan temperatur udara berkualitas tinggi, jauh lebih presisi dan durable dibandingkan sensor DHT11. Sensor DHT 21 ditunjukkan pada gambar 4 (Wiryadinata dkk., 2014).

Spesifikasi: 
- Model: AM2301

- Humidity and Temperature sensor using 1 wire serial interface

- Dimension: 59 x 27 x $13 \mathrm{~mm}$

- Input: $3.5 \mathrm{~V}-5.5 \mathrm{~V}$

- $1-1.5 \mathrm{~mA}$ measuring current

- Humidity from 0-100\% RH

- Temperature Range: -40 to 80 degrees $\mathrm{C}$

- Accuracy: +-3\% RH and +-0.5 degrees C

- Wire length: $25 \mathrm{~cm}$

- Ultra-low power, Excellent long-term stability, Digital output

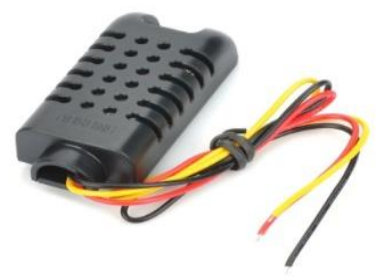

Gambar 4. Sensor DHT 21

\section{LCD M1632}

Display LCD 16x2 LCD (Liquid Cristal Display) adalah salah satu komponen elektronika yang berfungsi sebagai tampilan suatu data, baik karakter, huruf ataupun grafik dilihat pada Gambar 5 (Supriyono dan Tatyantoro, 2011).

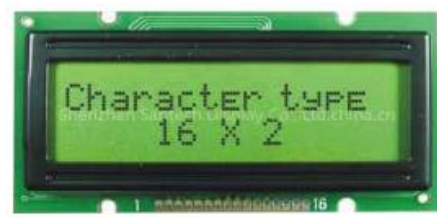

Gambar 5. LCD

\section{Arduino Uno}

Arduino UNO adalah sebuah board mikrokontroler yang didasarkan pada ATmega328 (data sheet).Arduino UNO mempunyai 14 pin digital input atau output (6 di antaranya dapat digunakan sebagai output PWM), 6 input analog, sebuah osilator Kristal $16 \mathrm{MHz}$, sebuah koneksi USB, sebuah power jack, sebuah ICSP header, dan sebuat tombol reset. Arduino UNO memuat semua yang dibutuhkan untuk membantu mikrokontroler, mudah menghubungkannya ke sebuah komputer dengan sebuah kabel USB atau mensuplainya dengan sebuah adaptor ACke DC atau menggunakan baterai untuk memulainya dilihat pada Gambar 6 (Setiawan, 2014).

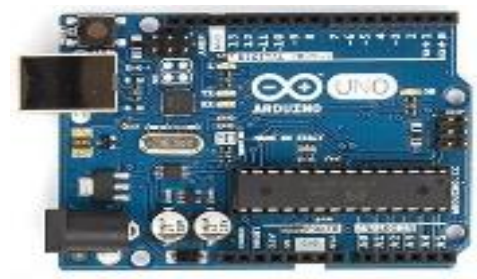

Gambar 6. Arduino Uno 


\section{METODE PENGABDIAN}

\section{Mesin pengering hasil kebun serbaguna}

Mesin pengering hasil kebun serbaguna ini merupakan mesin yang dapat digunakan untuk pengolahan dan pengeringan hasil perkebunan seperti ketela pohon, daging kelapa, pisang dan produk lainnya. Prinsip kerjanya adalah memanfaatkan energi matahari yang diserap oleh komponen pemanas dimana terletak dibawah rak-rak penjemur. Komponen utama mesin pengering serbaguna ini meliputi rumah pengering dari kaca, rak-rak pengering, komponen pemanas dari lempeng pelat kuningan dan ditambah dengan elemen pemanas jika cuaca tidak mendukung seperti mendung, hujan dan malam hari. Mesin pengering serbaguna ini dapat digunakan pada siang dan malam hari. Komponen mesin pengering ini dapat dilihat pada Gambar 7.

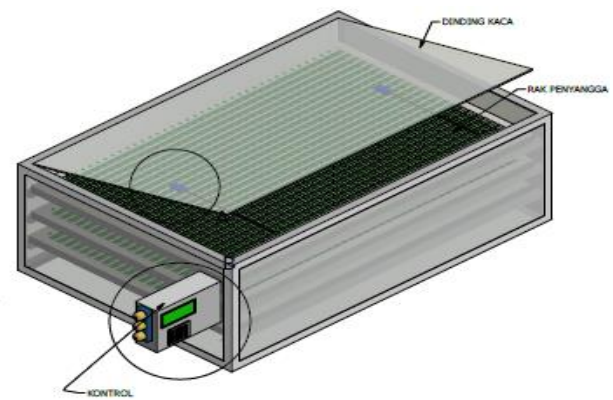

Gambar 7. Komponen Mesin Pengering Serbaguna

\section{Komponen Utama Mesin pengering hasil kebun serbaguna}

1. Rangka

2. Rak penjemur

3. Rumah pengering

4. Kolektor matahari

5. Komponen pemanas

6. Elemen pemanas

7. Sistem pengontrolan menggunakan mikrokontroler arduino uno

Untuk menanggulangi permasalahan yang telah dirumuskan, diperlukan suatu pemecahan agar tercapai tujuan yang diinginkan. Untuk itu dilakukan beberapa tahap pemecahan yaitu:

1. Tahapan Persiapan, meliputi:

a. Pendaftaran calon peserta pelatihan.

b. Penyusunan materi pelatihan dan instrumen untuk seleksi dan perekrutan bagi peserta pelatihan.

c. Koordinasi dengan kepala desa serta camat setempat untuk konsolidasi pelaksanaan pelatihan.

d. Pembuatan job sheet.

e. Persiapan alat bantu pengajaran.

f. Penyiapan pelatihan objek.

g. Pembuatan jadwal pelatihan dan membagi kelompok. 
2. Tahap Pelaksanaan, meliputi:

a. Perekrutan

Peserta yang mengikuti pelatihan sebanyak 30 orang yang berasal dari masyarakat petani atau pengolah hasil kebun di Desa Pasar Padati dan Desa Harapan Kecamatan Pondok Kelapa Kabupaten Bengkulu Utara, sekaligus sebagai membuka peluang lapangan kerja baru dan mengurangi pengangguran.

b. Penyampaian materi Modul Pelatihan pembuatan mesin pengering serbaguna untuk pengolahan dan pengeringan hasil perkebunan.

c. Praktek pengenalan komponen utama mesin pengering dan fungsi masing-masing komponen.

d. Praktek pembuatan mesin pengering serbaguna untuk pengolahan dan pengeringan hasil perkebunan.

e. Praktek penggunaan dan perawatan mesin pengering serbaguna untuk produk ketela pohon, kopra, pisang dan hasil kebun lainnya.

3. Tahap Evaluasi Kegiatan, meliputi :

a. Uji kemampuan dasar materi pelatihan pembuatan dan penggunaan mesin pengering serbaguna untuk pengembangan kemampuan atau soft skill Bagi masyarakat sebanyak 10 soal Essay Test.

b. Uji praktek Pengetahuan tentang Komponen mesin pengering serbaguna dan cara pembuatannya (wawancara langsung satu persatu peserta).

c. Uji praktek pembuatan dan penggunaan mesin pengering serbaguna, pemilihan bahan dan proses (wawancara langsung satu persatu peserta).

d. Uji praktek pengeringan menggunakan mesin pengering serbaguna yang dilakukan langsung perkelompok.

Prosedur kerja untuk mendukung realisasi metode melalui pengabdian Ipteks bagi masyarakat yang meliputi persiapan, pelatihan dan pembuatan alat ini dilakukan dalam 8 bulan.

Rencana kegiatan yang menunjukkan langkah-langkah penerapan pengabdian masyarakat di Desa Pasar Pedati dan Desa Harapan Kecamatan Pondok Kelapa dengan melibatkan 30 orang dengan berbagai tahapan sebagai berikut:

\section{a. Tahapan Rencana tindakan}

Penerapan teknologi ini menggunakan metode pendekatan pelatihan campuran. tahap pertama dengan menggunakan teknik inovasi dan kreatifitas membuka wawasan pengetahuan masyarakat akan mesin pengering yang ramah lingkungan, mudah dibuat dengan harga terjangkau dan aplikasi dari mesin pengering serbaguna serta sumber energi yang digunakan. Tahap kedua dengan menggali kemampuan dasar masyarakat dalam proses perencanaan dan pembuatan mesin pengering serbaguna. Tahap selanjutnya adalah membuat dan menguji mesin pengering serbaguna agar langsung menghasilkan produk dengan kualitas pengeringan yang baik, waktu pengeringan yang cepat dan higienis. Serta diakhiri cara melakukan perawatan/pemeliharaan alat agar dapat digunakan dalam waktu yang lama. Subjek penelitian dalam hal ini adalah masyarakat Kelompok Tani penghasil kebun ketela pohon, pisang dan kopra di Desa Pasar Pedati dan Desa Harapan Kecamatan Pondok Kelapa Kabupaten Bengkulu Utara. Langkah-langkah kegiatan yang dilakukan adalah sebagai berikut:

1. Kegiatan ini diawali dengan diskusi antara pendamping pelatihan dengan pemuka masyarakat (Kepala Desa, Sekretaris Desa dan masyarakat petani). 
2. Pendamping melakukan interview peserta untuk mengetahui wawasan mereka tentang proses pengolahan hasil kebun dan aplikasi penggunaan mesin pengering hasil kebun serbaguna.

3. Pendamping memberi pengarahan dan materi tentang proses perancangan, pembuatan dan penggunaan mesin pengering serbaguna untuk pengolahan hasil panen ketela pohon, pisang dan kopra.

4. Berdasarkan data hasil interview dan pengamatan sebelumnya dilakukan diskusi tentang pemahaman peserta pelatihan tentang proses pembuatan dan penggunaan mesin pengering serbaguna untuk pengolahan hasil panen ketela pohon, pisang dan kopra.

5. Pendamping dan peserta berdiskusi rencana keterampilan untuk pertemuan berikutnya.

6. Pendamping memberi teori tentang mesin pengering serbaguna dan komponenkomponennya untuk pengolahan hasil panen ketela pohon, pisang dan kopra serta mempraktekkan teori-teori tersebut.

7. Pendamping memberi kesempatan para peserta untuk membuat mesin pengering secara berkelompok dan individu.

8. Pendamping mengamati kemampuan yang telah dimiliki peserta.

9. Menetapkan keberhasilan tahapan awal dalam bereksperimen.

\section{b. Tahapan Pelaksanaan Tindakan}

1. Pada tahap pelaksanaan lanjutan dimulai dengan pemberian materi dan informasi tentang aplikasi mesin pengering serbaguna menggunakan energi matahari, komponen pemanas, pemilihan bahan dan proses pembuatan serta permasalahan yang sering timbul pada saat membuat dan menggunakan mesin pengering serbaguna.

2. Pendamping memberi beberapa contoh dalam pelatihan proses pembuatan mesin pengering serbaguna.

3. Pendamping memberi pengarahan sekaligus eksperimen penggunaan mesin pengering serbaguna.

\section{c. Tahapan Observasi}

1. Pada tahap observasi, kegiatan yang dilakukan pendamping adalah mengamati setiap tindakan peserta dalam bereksperimen dan melakukan ujian tertulis tentang pengetahuan yang telah dimiliki.

2. Pendamping bersama dengan peserta mendiskusikan permasalahan proses pengeringan berupa kualitas hasil pengeringan, waktu pengeringan dan bahan komponen pengeringan.

3. Pendamping kembali melakukan evaluasi secara tertulis terhadap tindakan yang telah dilakukan peserta.

4. Pendamping mengidentifikasi capaian yang diperoleh oleh peserta.

5. Pendamping melakukan evaluasi penyebab kekurangan yang terjadi saat pembuatan dan penggunaan mesin pengering dan merumuskan kembali cara memperbaiki halhal yang kurang berhasil.

\section{d. Tahapan Metode Pengumpulan Data Dan Analisa Data}

1. Pengumpulan data tentang proses yang dicapai menggunakan metode observasi dan wawancara. 
2. Observasi dilakukan untuk mengamati keterampilan peserta secara individual.

3. Wawancara digunakan untuk mengetahui tanggapan peserta terhadap pengetahuan yang telah didapat.

\section{HASIL DAN PEMBAHASAN}

\section{Hasil Pengabdian Kepada Masyarakat IbM}

Pelaksanaan pelatihan pembuatan mesin pengering serbaguna untuk hasil kebun seperti ubi kayu, pisang, kelapa dan hasil kebun lainnya ini memberikan alih ilmu pengetahuan dan teknologi kepada masyarakat tani dalam pengolahan hasil kebun. Kelapa dan ubi singkong hasil kebun biasanya dikeringkan dengan dijemur pada arak-rak bambu seperti terlihat pada Gambar 4. Dimana proses pengeringan ini sangat mudah terkontaminasi oleh kotoran dan debu yang dibawa oleh udara. Waktu pengeringan yang dibutuhkan berkisar antara 6-7 hari (tergantung cuaca).

Dalam pelatihan ini dibuat mesin pengering serbaguna seperti terlihat pada Gambar 5. Hasil kebun dikeringkan dalam rak-rak pengering yang terbuat dari pelat tembaga. Material tembaga merupakan penghantar panas yang baik dalam proses pengeringan. Penggunaan mesin ini dapat mengurangi waktu pengeringan, kebersihan lebih terjamin dan tidak memerlukan dominasi operator dalam pengolahan hasil kebun terutama untuk membolak-balik kelapa atau ubi singkong, mengangkat kedalam rumah jika hari hujan dan lainnya.

Pelatihan pembuatan dan pemanfaatan mesin pengering serbaguna ini diikuti oleh masyarakat desa telah meningkatkan kemampuan masyarakat dalam mengolah hasil pertanian atau perkebunan yang cepat, hemat waktu, higienis dan kualitas terkontrol dengan memanfaatkan kolektor matahari dan sumber energi surya.
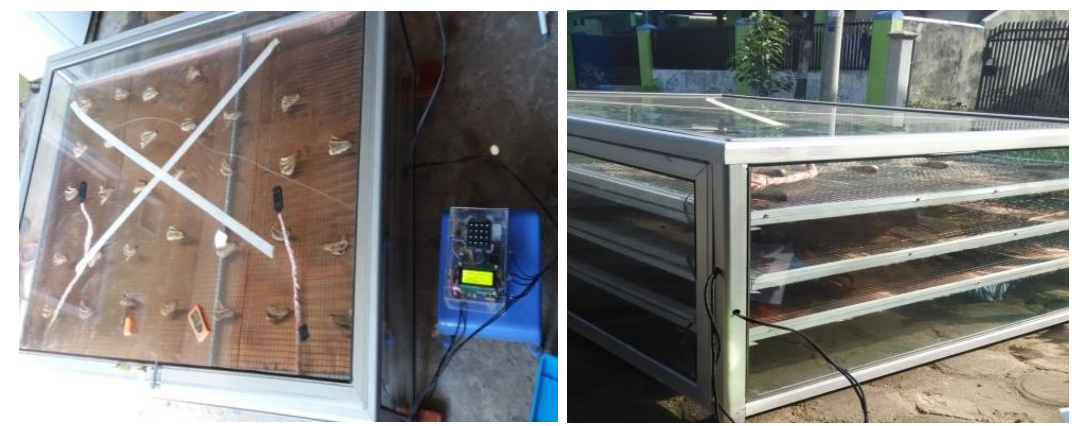

Gambar 8. Mesin Pengering Serbaguna dengan Rak-Rak Tembaga

Tahapan proses pelatihan yang meliputi pengenalan komponen mesin pengering serbaguna memanfaatkan energi matahari, cara pembuatan mesin pengering, perangkaian dan pemasangan komponen. Pengenalan komponen meliputi:

1. Rangka mesin pengering

Rangka pengering berfungsi sebagai tempat pemasangan kaca terbuat dari bahan aluminium yang dipasang menggunakan baut. Aluminium dipotong sesuai ukuran mesin pengering kemudian dirangkai dan dipasang kaca pada bagian rumah pengering. Bentuk rangka dapat dilihat pada Gambar 5.

2. Rumah pengering.

Rumah pengering terdiri dari kaca tebal $5 \mathrm{~mm}$ yang dipasang di sekeliling rumah pengering. Kaca berfungsi untuk menahan panas yang berada didalam rumah pengering. 
Panas didapatkan dari energi matahari yang menyinari pelat tembaga sebagai bagian dari komponen rak-rak pengering.

3. Rak-rak pengering.

Rak pengering berfungsi sebagai tempat dudukan atau penjemuran produk seperti kelapa dan ubi singkong. Rak terbuat dari jaring-jaring kawat yang berada di atas lempeng pelat tembaga. Rak-rak disusun dalam beberapa tingkat dimana disetiap tingkat akan mendapatkan panas dari lempeng tembaga. Panas ini akan mengeringkan kelapa dan ubi kayu atau hasil perkebunan lainnya.

Bahan dan peralatan yang digunakan untuk membuat mesin pengering ini adalah aluminium, kaca, pelat tembaga, jaring kawat, baut dan komponen lainnya.
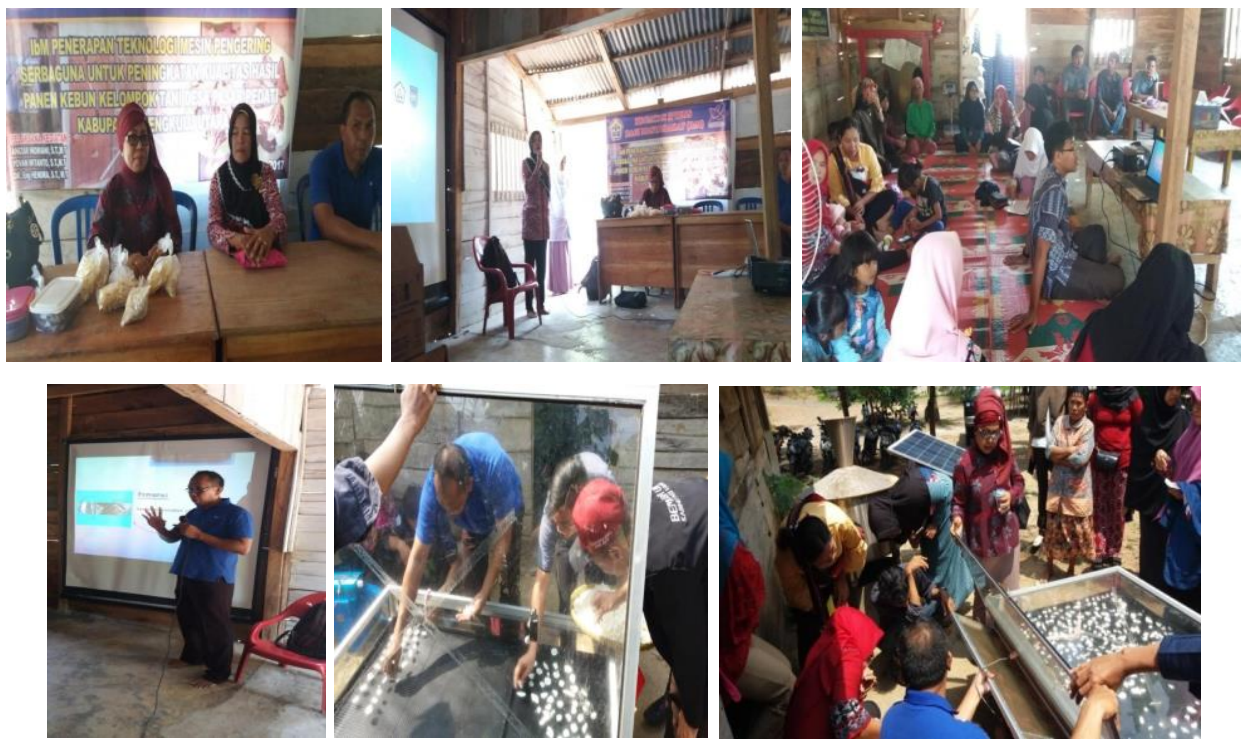

Gambar 9. Peserta Pelatihan Sistem Pengering Serba Guna Di Desa Pasar Pedati
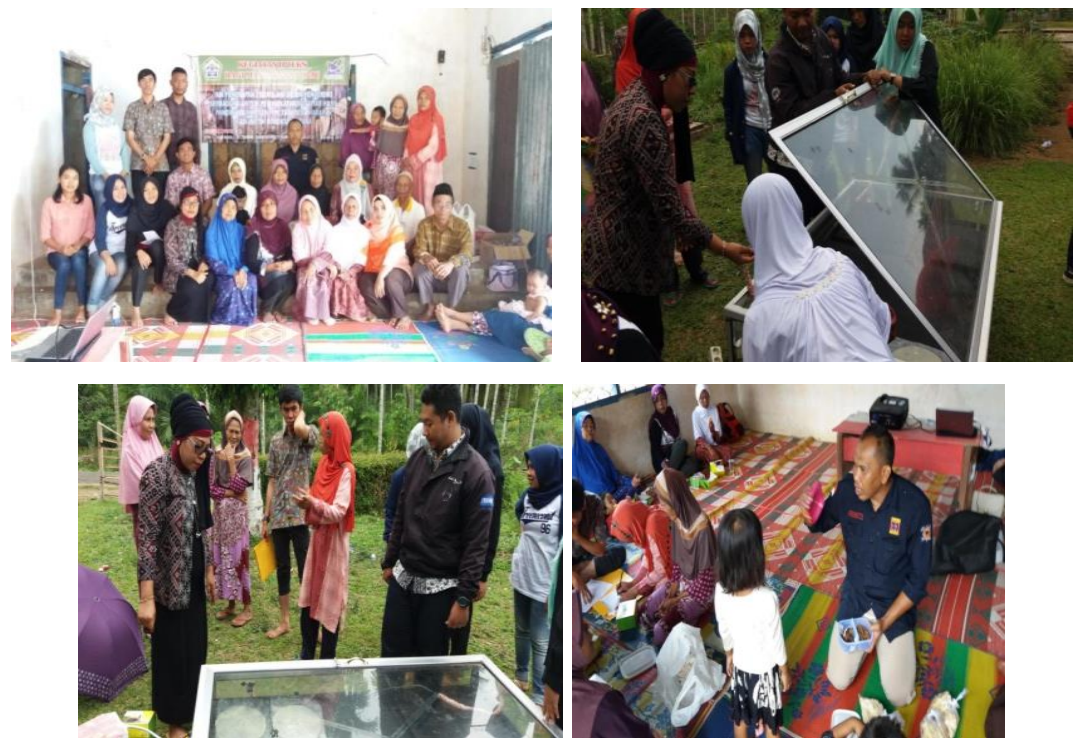

Gambar 10. Peserta Pelatihan Sistem Pengering Serba Guna Di Desa Harapan 
Cara pembuatan mesin pengering ini adalah:

1. Pembuatan rangka mesin pengering dari aluminium dengan ukuran seperti terlihat pada Gambar 2.

2. Pemasangan kaca pada rangka mesin pengering.

3. Pemotongan kawat untuk rak-rak pengering dilanjutkan dengan pembuatan rak-rak pengering.

4. Pemotongan pelat tembaga untuk media penyerap panas didalam rumah pengering.

5. Pemasangan semua komponen kedalam rumah pengering menggunakan baut dan paku keeling.

Peserta pelatihan dapat dilihat pada Gambar 6 dan 7, dimana terlihat bahwa alat ini juga dapat dibuat dan digunakan oleh kaum ibu. Dimana di desa ini kaum ibu lebih banyak berada di rumah dan suami atau kaum lelaki bekerja di kebun atau keluar desa. Untuk kaum lelaki pekerjaannya selain mengambil nira juga berkebun. Hal ini menunjukan alat atau mesin pengering serbaguna ini sangat bermanfaat dan dapat digunakan oleh semua khalayak masyarakat dewasa.

\section{KESIMPULAN}

Kesimpulan yang didapat dari pengabdian masyarakat IbM Ipteks bagi masyarakat ini adalah:

1. Mesin pengering serbaguna terbuat dari bahan aluminium, kaca, tembaga dan jaring kawat.

2. Waktu dan hasil pengeringan lebih singkat dan bersih.

3. Masyarakat peserta pelatihan khususnya kaum wanita atau ibu rumah tangga menunjukan bahwa mereka dapat membuat dan menggunakan mesin pengering serbaguna dalam membantu suami atau keluarga dalam proses pengolahan hasil perkebunan atau pertanian seperti ubi, kelapa dan Kopra.

\section{DAFTAR PUSTAKA}

Setiawan, Dany, 2014, Arduino Uno, Ilmu Teknologi dan Informasi: ilmuti.org.

Subandi dan Salmet Hani, 2015, Pembangkit Listrik Tenaga Matahari Sebagai Penggerak Pompa Air Dengan Menggunakan Solar Cell, Jurnal Teknologi Technoscientia, Vol.7 No.2.

Supriyono, Selo dan Tatyantoro Andrasto, 2011, Pemantau Temeperatur dan Kelembaban Pada Rumah Kaca Berbasis Mikrokontroler ATMEGA8535, Jurnal Teknik Elektro, Vol.3 No.2.

Wijaya, Ade Mundari, 2011, Rancang Bangun Alat Pemanas dan Pengaduk Terintegrasi Dengan Temperatur dan Kecepatan Terkendali Berbasis Mikrokontroler, Publikasi Skripsi, Universitas Indonesia, Depok.

Wiryadinata, Romi, Joko Lelono dan Alimuddin, 2014, Aplikasi Sensor LDR (Light Dependent Resistor) Sebagai Pendeteksi Warna Berbasis Mkrokontroler, Jurnal Sistem Komputer, Vol.4 No.1. 